\title{
Seasonal fluctuations in environmental factors and variations in symbiotic algae and chlorophyll pigments in four Indo-Pacific coral species
}

\author{
B. E. Brown ${ }^{1, *}$, R. P. Dunne ${ }^{1}$, I. Ambarsari ${ }^{1}$, M. D. A. Le Tissier ${ }^{1}$, U. Satapoomin ${ }^{2}$ \\ ${ }^{1}$ Department of Marine Sciences and Coastal Management, University of Newcastle upon Tyne, Newcastle NE1 7RU, \\ United Kingdom \\ ${ }^{2}$ Phuket Marine Biological Center, PO Box 60, Phuket 83000, Thailand
}

\begin{abstract}
Marked seasonality is observed in sea-surface temperature (SST) and photosynthetically active radiation (PAR) received by shallow water corals at Phuket, Thailand $\left(7^{\circ} \mathrm{N}\right.$ latitude). This seasonality is reflected in both algal densities and algal chlorophylls $\left(a\right.$ and $c_{2}$ ) in 4 massive species of scleractinian corals, namely Coeloseris mayeri, Goniastrea retiformis, Porites lutea, and $G$. aspera. Algal numbers and algal chlorophylls are generally maximal at the end of the wet season (November) and minimal at the end of the dry season (March to May). Algal densities are reduced by up to $53 \%$ in May compared to November in some species, while algal chlorophylls may be up to 4 -fold greater in November. Concomitant with these changes are differences in algal cell volume in 3 out of the 4 species studied and alterations in host tissue depth, with smaller algal volume and greater tissue depth at the end of the wet compared with the dry season. Over the period 1993 to 1996 algal numbers showed a significant negative correlation with monthly ( $30 \mathrm{~d}$ ) and short-term ( 1 to 2 d) values of both SST and PAR dose, while algal chlorophylls displayed a significant negative correlation with PAR dose in the $5 \mathrm{~d}$ preceding collection. Rising SST and increasing PAR in the dry season are paralleled by decreasing algal numbers and algal chlorophylls on an annual basis. Recovery of algal densities and a build-up in algal chlorophylls follow reductions in SST and PAR at the end of the wet season. In one of the years, when coral 'bleaching' was widespread at the study site (May 1995), the interaction between SST and PAR resulted in an $86 \%$ reduction in algal densities in bleached corals compared to their annual maximum density. This study highlights the importance of seasonal fluctuations in physical environmental parameters and concomitant changes in the coral/algal symbiosis. Furthermore, it emphasises the need for greater understanding of the potential effects of seasonal and inter-annual variability on the status of algal symbionts, as well as identification of critical times of the year when visible bleaching may not be obvious but when algal numbers and algal chlorophylls are low and effects on coral physiology may be far-reaching
\end{abstract}

KEY WORDS: Zooxanthellae $\cdot$ Chlorophyll $\cdot$ Solar radiation $\cdot$ Sea temperature $\cdot$ Nutrients

\section{INTRODUCTION}

It has now been recognised that coral reefs are not stable communities living in benign environments, freed from seasonal fluctuations, as suggested by Newell (1971) and more recently by Adey (1998). Instead they are ecosystems subject to frequent disturbances on time scales of minutes to years (Done 1992, Woodley 1992, Veron 1995). Seasonality affects all reefs as evidenced by the seasonal banding patterns in

•E-mail: 101515.1267@compuserve.com massive coral skeletons worldwide (Buddemeier \& Kinzie 1976), in coral reproductive patterns (Stoddart \& Black 1985, Wallace 1985, Chornesky \& Peters 1987 , Rinkevich \& Loya 1987, Harrison \& Wallace 1990), in patterns of nutrition (Rinkevich 1989) and in regeneration (Van Veghel \& Bak 1994).

Given the fundamental role of the algal symbiosis in meeting the energy budget of corals, seasonal changes in many aspects of coral physiology are likely governed by the dynamic relationship between the host and its algae, which is in turn influenced by environmental factors such as seawater temperature, irradi- 
ance, rainfall, salinity, nutrients and tidal range (see Brown 1997 a for review). Little is known, however, of the effects of seasonality on some of the most fundamental photophysiological parameters such as coral algal densities and algal pigment content. Stimson (1997), using Pocillopora damicornis from Hawaii, suggested that coral algal density responded to seasonal differences in environmental parameters with a negative correlation between algal density and solar radiation, and a positive correlation between algal density and the concentration of dissolved $\mathrm{NO}_{3}$ in any month. No significant correlation was obtained between seasonal variations in seawater temperature and coral algal density. Fagoonee et al. (1999) observed fluctuations in symbiotic algal density in the coral Acropora formosa in Mauritius which correlated with seawater nitrate concentrations and time of year from samples collected on an approximately weekly basis over a $5 \mathrm{yr}$ period. Verde \& McCloskey (1998) studied seasonal influences on the photophysiology of the symbiotic jelly fish Cassiopea xamachana and demonstrated significant fluctuations in algal size and algal pigment (chlorophylls $a$ and $c_{2}$ [chls $a$ and $c_{2}$ ]) content throughout the year, but did not observe seasonal variations in algal densities. Working on the branching coral Acropora formosa from the northern Great Barrier Reef, Jones \& Yellowlees (1997) did not detect any seasonal changes in coral algal densities, concluding that this finding was consistent with the fact that algal density is set close to the upper maximum limit determined by space availability. However, other workers on the Great Barrier Reef have suggested that there may be seasonal and year-to-year variations in animal tissue depth in massive coral species (Barnes \& Lough 1992), thereby altering the space available for occupation by symbiotic algae at different times of the year.

In the present study a variety of photophysiological parameters were investigated in the symbiotic algae of 4 intertidal coral species over a 4 yr period from 1992 to 1996. The 4 massive coral species sampled were Goniastrea aspera, G. retiformis, Coeloseris mayeri and Porites lutea. The aim of the study was to investigate seasonal variation in selected environmental parameters (specifically seawater temperature and underwater photosynthetically active radiation [PAR]) and their potential links with variations in algal density, algal size, and algal chlorophyll content (chls a and $c_{2}$ ).

\section{MATERIAL AND METHODS}

Study site and measurements of environmental variables. The study site is located on the southeast tip of Ko Phuket, Thailand, in the Andaman Sea $\left(7^{\circ} 48^{\prime} \mathrm{N}\right.$, $98^{\circ} 24.5^{\prime} \mathrm{E}$ ). Physical characteristics of the location (Site
A in Brown et al. 1994) are described in detail in Brown et al. (1986) and Scoffin et al. (1992). At Site A a wide intertidal reef flat extends for a distance of up to $200 \mathrm{~m}$ from the shore, where it terminates in a shallow forereef extending to a depth of $5 \mathrm{~m}$. The reef is dominated by massive coral species tolerant of high sedimentation.

Sea-surface temperature: Sea-surface temperature (SST) was measured using a precision thermistor probe located $0.5 \mathrm{~m}$ below chart datum approximately $1 \mathrm{~km}$ from the study site in a body of well-mixed water which flushes across the site on the tidal cycle $(\sim 1$ to 1.5 knots [ 0.5 to $\left.0.8 \mathrm{~m} \mathrm{~s}^{-1}\right]$ ). Measurements were made every $10 \mathrm{~min}$, and averaged hourly. The thermistor was calibrated prior to installation in February 1993 $\left( \pm 0.04^{\circ} \mathrm{C}\right)$. An in situ cross calibration was made in February 1997 with a newly calibrated Seamon temperature recorder (Hugrún, Reykjavik, Iceland). Data for bulk SST for the sea area $\left(5^{\circ} \times 5^{\circ}\right.$ lat./long. grid) were also obtained from the Meteorological Office Historical Sea Surface Temperature data set, MOHSST 6.1 (Parker et al. 1995).

Surface solar radiation: Global solar radiation was recorded continuously from February 1993 to December 1996 at Phuket Marine Biological Center (PMBC), $1.5 \mathrm{~km}$ from the study site, using a suite of thermopile and photodiode sensors. The principal record presented in this paper is from a PAR (400 to $700 \mathrm{~nm}$ ) $2 \pi$ cosine-corrected sensor (Macam Photometrics SD 101QV-Cos), recording global downwelling irradiance. Readings were taken at $1 \mathrm{~min}$ intervals, averaged and logged every $10 \mathrm{~min}$. The sensor output was calibrated periodically against a scanning spectroradiometer and monitored for long-term changes against the output from a thermopile type device (Tube Solarimeter: Szeicz et al. 1964, Green \& Deuchar 1985). Data were corrected, using the thermopile record, for any long-term sensor variations. Two months of the record (February and March 1994) were computed from the thermopile recordings during a period of PAR sensor malfunction.

Calculation of actual PAR received by corals on the reef flat: Actual PAR received by corals was determined using the measurements of surface PAR from the PMBC sensor. PAR during periods of sub-aerial exposure was related directly to this record, whilst during submergence the PAR was computed from the relationship:

$$
E_{\mathrm{d}}(Z)=E_{\mathrm{d}}\left(0^{-}\right) \mathrm{e}^{-K_{\mathrm{d}} Z}
$$

where $E_{\mathrm{d}}(Z)$ is the value of global downwelling irradiance at depth $Z \mathrm{~m}, E_{\mathrm{d}}\left(0^{-}\right)$is the value of global downwelling just below the water surface, and $K_{\mathrm{d}}$ is the average value of the diffuse attenuation coefficient for downwelling irradiance for the depth interval $0^{-}$to 
$Z \mathrm{~m} . E_{\mathrm{d}}\left(0^{-}\right)$was derived from the above water irradiance by assuming an irradiance transmittance through the air-sea interface of $96 \%$. This average value holds good for wind speeds $<5 \mathrm{~m} \mathrm{~s}^{-1}$ and sun altitudes $>46^{\circ}$ (Gregg \& Carder 1990).

A value of $K_{\mathrm{d}}\left(0.501 \mathrm{~m}^{-1}\right)$ was derived empirically from measurements of underwater PAR which were recorded in situ on the reef flat in 1998 (Dunne unpubl.). Water depth was computed from the tidal record for Ko Taphao Noi for the years 1992 to 1995 at hourly intervals and interpolated to give intermediate 10 min data points. For the short-term data set in 1996 this tidal record was not available and tidal height was predicted from TideCalc (NP 158) Version 1.1 (Hydgrographic Office, UK) using the harmonic constants for Ko Taphao Noi. Downwelling irradiance was computed for each coral species based on levelling data of mean heights of colonies relative to the tidal datum.

Mean sea level: The tidal form is semi-diurnal with a spring tide range of $3.1 \mathrm{~m}$ and a neap range of $1 \mathrm{~m}$. For the purpose of this study, variations in mean sea level were examined on a monthly basis from the tidal record of Ko Taphao Noi tide gauge station located $2.5 \mathrm{~km}$ from the study site. Monthly mean sea level data and the hourly sea level record were obtained from the University of Hawaii/National Oceanographic Data Center Joint Archive for Sea Level for the period January 1992 to December 1995 (GLOSS station number 042). The detailed (hourly) record was validated against local datum points at the study site during periods of fieldwork

Rainfall and nutrients: Monthly rainfall data were obtained from the Meteorological Station in Phuket town, approximately $10 \mathrm{~km}$ away. Dissolved nutrient $\left(\mathrm{NO}_{3}, \mathrm{NO}_{2}, \mathrm{PO}_{4}\right)$ and salinity data were sampled at Phuket Biological Center pier for the period 1992 to 1996 (Jarekarn \& Khokiattiwong unpubl.). Dissolved nutrient data were also collected at Ao Kham, adjacent to the site, from 1993 to 1998 (Khokiattiwong unpubl.). In most cases the water samples were taken every $2 \mathrm{wk}$ and were analysed using the methods of Strickland \& Parsons (1968).

Sampling of corals. Four intertidal reef flat coral species were sampled approximately every 3 mo over the 4 yr period 1992 to 1996 . These species were Goniastrea aspera, G. retiformis, Coeloseris mayeri, and Porites lutea. All species (apart from $G$. aspera) were sampled in July and November in 1992; March, May, August and December in 1993; March, May, August and November in 1994; February, May, June, July and November in 1995; and February 1996. Sampling of $G$. aspera began in March 1993 and was carried out in parallel with other coral species at subsequent dates, apart from an additional sample in February 1994. Collections were always made from pigmented corals apart from in May 1995, when colonies appeared pale. In June 1995, when many corals had bleached white, samples were collected from pigmented colonies (which were still noticeably paler in colour), and additional samples were taken for comparison from colonies which had bleached white.

In addition, samples were collected from Goniastrea aspera approximately every $3 \mathrm{~d}$ throughout a $50 \mathrm{~d}$ period, from 3 February to 23 March 1996. This period encompassed 3 spring/neap tide sequences and was chosen to identify factors that might cause short-term variability within the long-term temporal data set.

On each sampling date 2 coral cores $(25 \mathrm{~mm}$ diameter) were sampled from the apex of 10 randomly chosen coral colonies of each species, using a drill fitted with a hole-saw bit. In June 1995 cores were also sampled from 5 bleached colonies. All cores were removed from colonies within the first $30 \mathrm{~min}$ of sub-aerial exposure on the low tide. One set of cores was used for measurement of symbiotic algal densities and the other for chlorophyll measurements. Core surface areas were computed from diameters measured with vernier calipers

Measurement of algal densities and algal diameters. Cores were fixed in $10 \%$ formalin $(24 \mathrm{~h})$, decalcified in $5 \%$ formic acid $/ 5 \%$ formalin ( $48 \mathrm{~h}$ ) and homogenised in $2 \%$ formalin using a tissue tearer (Ultra Turrax T25 at $13500 \mathrm{rpm}$ ). Homogenisation was considered complete when no clumps of tissue remained but zooxanthellae remained intact. Zooxanthellae from 3 sub-samples from each core were counted microscopically on Neubauer haemocytometer slides and counts normalised to coral surface area.

Following initial analysis of algal densities, diameters of algae were measured from periods of high (December 1993) and low algal density (March 1994) in all coral species. Maximum algal diameters were measured from 25 algae isolated from each of 5 colonies of each coral species at $\times 1000$ magnification under oil immersion. These values were then used to compute volume, assuming each alga to be spherical.

Measurement of chlorophyll concentrations. Excess skeleton below the tissue layer was cut away and discarded. Cores were then ground using a pestle and mortar in $10 \mathrm{ml} 90 \%$ acetone following the method of Jeffrey \& Haxo (1968). Chlorophyll absorbances were read at $750,664,647$ and $630 \mathrm{~nm}$ in a Whatman DC500 spectrophotometer (long-term sampling series) and a Hewlett Packard 8452A (short-term sampling series). Chlorophyll concentrations (chls $a$ and $c_{2}$ ) were calculated using the equations of Jeffrey \& Humphrey (1975) with the chl a component due to endolithic algae being subtracted (see Jokiel \& Coles 1974).

Statistical analysis of data. The environmental data time series were examined for long-term trends using 


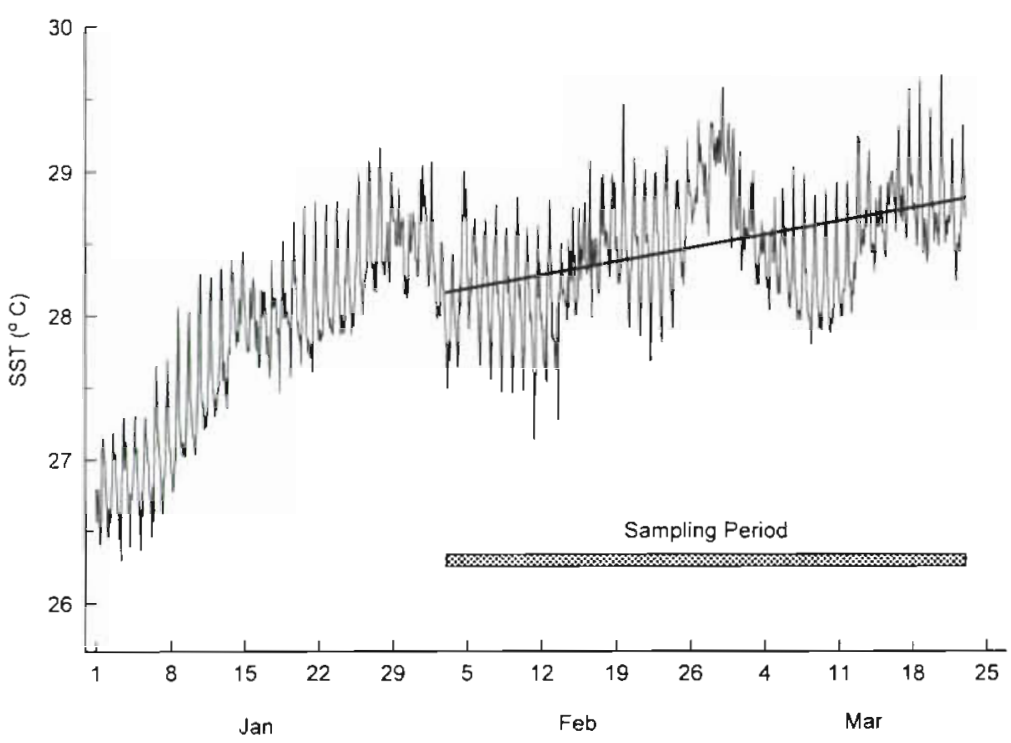

Fig. 1. Hourly record of sea-surface temperature (SST) prior to and during the sampling period in 1996. The straight line represents a regression of the mean daily SST between 3 February and $23 \mathrm{March}$ (slope 0.0129, p<0.0001,

$$
\mathrm{n}=50 \text { ) }
$$

linear regression (GraphPad Instat version 3.0 for Windows 95, GraphPad Software, San Diego, California, USA); seasonality was investigated either by decomposition analysis (Minitab release 10 for Windows, Minitab Inc., Pasadena, California, USA) or by curve fitting waveform functions using Tablecurve 2D v.3 (Jandel Scientific Software). Intra- and inter-annual comparisons of photophysiological parameters were carried out with ANOVA followed by SNK analysis where appropriate. For non-parametric data sets Kruskal-Wallis tests, followed by Dunn's multiple comparison analysis were used. Comparison of algal diameters between $\mathrm{De}$ cember 1993 and March 1994 was carried out using a 2-way ANOVA. In all cases involving multiple comparisons, $\alpha$ was maintained at 0.05 .

\section{RESULTS}

\section{Environmental parameters over short-term data set}

\section{Sea-surface temperature}

The hourly record of SST is shown in Fig. 1 for the month prior to, and for the $50 \mathrm{~d}$ sampling period. This time of year (the dry monsoon period) is charac- terised by clear skies and low rainfall. SST rises during these months, attaining its annual maximum in about May each year. This rise is shown in the record for January to March 1996. During the period of sampling the SST increased from a daily mean temperature of 28.16 to $28.81^{\circ} \mathrm{C}$, a difference of $0.65^{\circ} \mathrm{C}$, as shown by the regression line in Fig. 1 ( $p<0.0001, n=50)$. Just prior to and during the early part of the sampling period from 23 January to 10 February (18 d) the weather was unseasonably overcast and cool, resulting in the shortterm decrease in SST shown at the start of the sampling period, after a previous rapid increase during early January.

Photosynthetically active radiation (PAR) received by the corals

The daily PAR dose $\left(\mathrm{mol} \mathrm{m}^{-2} \mathrm{~d}^{-1}\right)$ received by apical surfaces of Goniastrea aspera on the reef is shown in Fig. 2 for the month preceding and for the period of sampling. The 2 primary factors controlling the PAR dose are the weather conditions and variations in the depth of water over the corals. These are both apparent in the record. The strong repeating pattern is due to the tidal function (also shown) so that the maximum daily dose occurs at the end of each neap tidal period when the

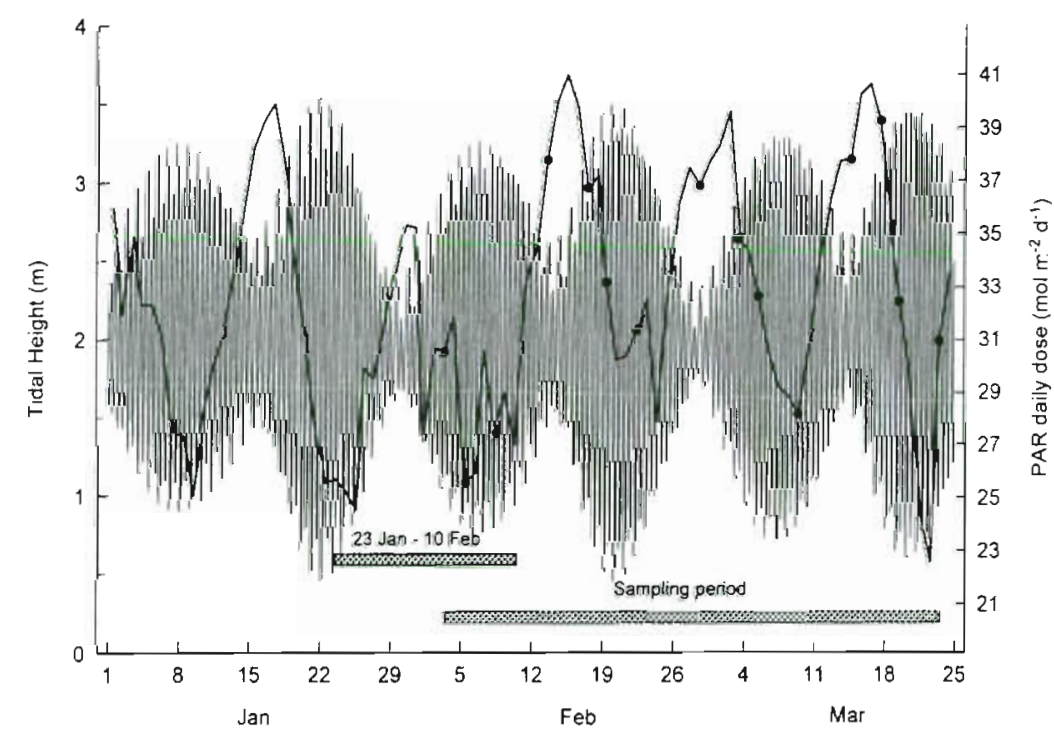

Fig. 2. Mean daily dose of PAR received by apical surfaces of colonies of Goniastrea aspera prior to and during the sampling period in 1996 (heavy line). -: Dates of coral sampling. The semi-diurnal tidal record and its cycle from neap to spring tides is also shown 
corals are covered by only about $20 \mathrm{~cm}$ of water during the central portion of each day at a time when solar irradiance is at its daily maximum. The daily dose then decreases during the spring tides, because, although the corals are exposed to full sunlight, first during the afternoon and then the morning sub-aerial exposure, the tidal cycle results in an increase in water depth during the middle of the day. For most of the record it is the sinusoidal tidal signal which predominates, because at this time of year clear sky conditions persist from day to day. The period of overcast weather mentioned above (23 January to 10 February) can be seen, with 1 peak cycle nearly lost and much greater day-today fluctuations. Over the period of sampling there was no significant long-term trend in PAR dose.

\section{Environmental parameters over long-term data set}

Environmental data over the period 1992 to 1996 are summarised in Fig. 3. A major influence at the study site is the reversing monsoon climate with the dry season (northeast monsoon) in November to April and the wet season (southwest monsoon) from May to October.

Sea-surface temperature

The monthly mean SST record demonstrates a strong seasonality (Fig. 3A) with no evidence of any long-term trend over the span of the data set (March 1993 to December 1996). The seasonality is described by a sinusoidal curve of the form:

$$
\text { Monthly mean SST }=a+b \cdot \sin (2 \pi \cdot x / d+c)
$$

where $a, b, c$, and $d$ are parameters. The term $x$ is the month number of the time series. Values of the parameters and the 'goodness of fit' are shown in Table 1. The peak monthly mean SST occurs each year in April (average $30.16^{\circ} \mathrm{C}$ ) and the minimum in January (average $28.03^{\circ} \mathrm{C}$ ). There is considerable evidence for a close coupling of SST to solar radiation, both at the diurnal scale, where the temperature oscillates by about $1.2^{\circ} \mathrm{C}$ between its coolest at $06: 00 \mathrm{~h}$ and warmest at 18:00 h (Dunne 1994), and at the scale of monthly

Table 1. Sinusoidal curve fitting parameters and goodness of fit data for photosynthetically active radiation (PAR) and seasurface temperature (SST) data (1993 to 1996)

\begin{tabular}{|crccccccc|}
\hline & \multicolumn{4}{c}{ Parameter } & \multicolumn{3}{c|}{ Goodness of fit } \\
& \multicolumn{1}{c}{$a$} & $b$ & $c$ & $d$ & F statistic & $\mathrm{p}$ & $\mathrm{r}^{2}$ \\
\hline PAR & 44.6 & 7.08 & 0.65 & 12.37 & 44.9 & $<0.0001$ & 0.75 \\
SST & 29.14 & 0.77 & 5.34 & 12.34 & 15.1 & $<0.0001$ & 0.53 \\
& & & & & & & \\
\hline
\end{tabular}

means. Iterative correlation analysis between the PAR and SST monthly mean data sets resulted in a maximum correlation at a 3 mo phase lag (maximum SST following maximum PAR; $\mathrm{n}=46, \mathrm{r}=0.51, \mathrm{p}<0.0003$ ). This 'coupling' is hardly surprising in view of the relatively shallow coastal waters in the region and the fact that the absorption of solar energy and its heating effect on water masses approaches $100 \%$.

In most of the long-term study years the monthly mean SST falls within the range of mean \pm 1 standard deviation for that particular month, but in 1995 the SST rose to $31.01^{\circ} \mathrm{C}$ in April and remained at this level for 2 mo. Extensive coral bleaching on the reef flats and slopes coincided with this period of elevated temperature (Brown et al. 1996).

\section{Surface solar radiation}

The record of solar radiation (350 to $2500 \mathrm{~nm}$ ) from the thermopile sensor was examined over a period of 4 yr (January 1993 to April 1997) encompassing the sampling period, in order to determine any long-term trends in the natural solar radiation, as an indication of any seasonal pattern, and to check the long-term stability of the silicon photodiode PAR sensor. The mean daily dose remained constant over the whole period at about $18 \mathrm{MJ} \mathrm{m} \mathrm{m}^{-2} \mathrm{~d}^{-1}$. Superimposed on this was a strong annual seasonality of $\pm 3 \mathrm{MJ} \mathrm{m}^{-2} \mathrm{~d}^{-1}$ (decomposition fit time series mean absolute percentage error $4.9 \%$ ). The highest mean daily dose occurs during the dry season month of February and the lowest during the wet season months of August and September. The surface PAR record (Fig. 3B) demonstrates a pattern similar to the thermopile sensor record. The seasonality can be described by a sine curve of the same form as for SST, but with different parameters and a phase shift (Table 1). The sinusoidal curve has a wavelength of $12 \mathrm{mo}$ and an amplitude of $14.3 \mathrm{~mol} \mathrm{~m}^{-2}$. Maximum daily mean PAR occurs in March (51.7 mol m-2 $\mathrm{d}^{-1}$ ) and minimum (37.5 $\mathrm{mol} \mathrm{m}^{-2} \mathrm{~d}^{-1}$ ) in August. The wet season daily mean PAR is on average $28 \%$ less than the dry season.

PAR received by the corals and the influence of sea level

Downwelling PAR received at the depth of the colonies of Goniastrea aspera is also shown in Fig. 3B, expressed as a monthly mean of the daily dose (mol $\mathrm{m}^{-2} \mathrm{~d}^{-1}$ ). The PAR follows the same seasonal pattern as the surface PAR but does not fit a sinusoidal function. The maximum seasonal values occur approximately 1 mo earlier than the surface PAR maximum in Febru- 

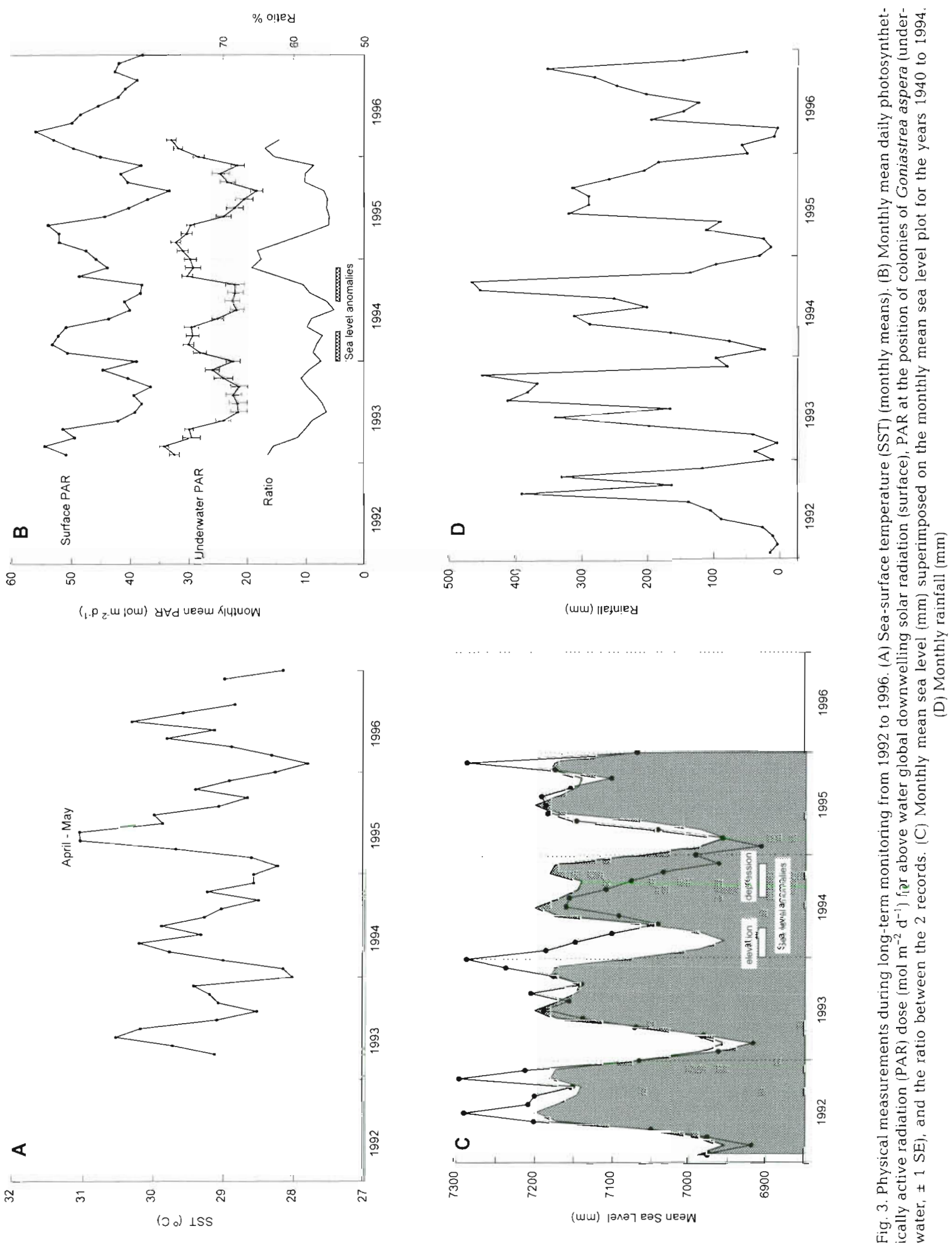
ary each year (mean $31.6 \mathrm{~mol} \mathrm{~m} \mathrm{~m}^{-2} \mathrm{~d}^{-1}$ ) whilst the minimum is again in August (mean $21.5 \mathrm{~mol} \mathrm{~m}^{-2} \mathrm{~d}^{-1}$ ). The wet season PAR is about $32 \%$ less than the dry season.

The ratio of PAR received by the corals compared to the surface PAR demonstrates a cyclical pattern, except in 1994. Since this ratio represents a 'filtering out' of changes in PAR due to weather patterns it follows that the 1994 anomalies must be a function of sea level factors. If the record of mean sea level (Fig. 3C) is examined, 2 anomalies occur in 1994. The first of these is an elevation of $10 \mathrm{~cm}$ in mean sea level between 1 December 1993 and 19 March 1994 (University of Hawaii Sea Level Center quality assessment) during a time when there should normally be a seasonal depression of about $20 \mathrm{~cm}$. This anomaly was corroborated from field observations at the time. The second anomaly involves a sea level depression around August to November 1994 of about 5 to $10 \mathrm{~cm}$ which has also been noted in the TOPEX/POSEIDON satellite altimeter record for the area (Chambers et al. 1999). Both of these anomalies will have a direct effect on the ratio and can be seen as a reduction in the ratio during the first anomaly followed by an elevation of the ratio during the second anomaly. It is likely that without these anomalies the PAR received by the corals would have demonstrated the same strong repetitive seasonality shown in the surface PAR, which would have resulted in a similar fitting of a sinusoidal function.

\section{Rainfall}

The rainfall pattern at Phuket is consistent with the reversing monsoon influence (Fig. 3D). Rainfall is normally minimal in the months from mid-December to mid-March, and consistently high in the wet season months from May to October.

\section{Salinity and nutrients}

Surface coastal waters have a relatively constant salinity of $32 \%$ irrespective of monsoon period (Panutrakul 1996). Dissolved nutrients $\left(\mathrm{NO}_{2}, \mathrm{NO}_{3}, \mathrm{PO}_{4}\right)$ are very variable and show no consistent patterns with season. Concentrations of nutrients in the coastal waters of Phuket are moderately high, being typical of other inshore locations experiencing eutrophication in the Florida Keys and Barbados (Table 2).

Table 2. Comparison of dissolved nutrient concentrations $(\mu \mathrm{M})$ at shallow, tropical locations worldwide with those measured at Phuket, Thailand. Mean values shown ( $\pm 1 \mathrm{SD}$ or ranges). "Total dissolved inorganic nitrogen including $\mathrm{NH}_{4}$

\begin{tabular}{|c|c|c|c|c|c|}
\hline Location & {$\left[\mathrm{NO}_{3}\right]$} & {$\left[\mathrm{NO}_{2}\right]$} & {$\left[\mathrm{PO}_{4}\right]$} & Sampling regime & Source \\
\hline Phuket, PMBC pier & $\begin{array}{c}0.612 \\
(0.007-5.1)\end{array}$ & $\begin{array}{c}0.101 \\
(0.002-0.347)\end{array}$ & $\begin{array}{c}0.197 \\
(0.001-0.806)\end{array}$ & $1992-1996(n \approx 70)$ & $\begin{array}{l}\text { Janekarn (unpubl.) } \\
\text { Khokiattiwong (unpubl.) }\end{array}$ \\
\hline Phuket, Ao Kham & $\begin{array}{c}1.2 \\
(0.001-7.8)\end{array}$ & $\begin{array}{c}0.14 \\
(0.003-0.67)\end{array}$ & $\begin{array}{c}0.21 \\
(0.001-0.97)\end{array}$ & $1993-1998(\mathrm{n} \approx 70)$ & Khokiattiwong (unpubl.) \\
\hline $\begin{array}{l}\text { Kaneohe Bay, } \\
\text { Hawaii }\end{array}$ & $\begin{array}{c}0.09 \\
10.07)\end{array}$ & & $\begin{array}{c}0.09 \\
(0.05)\end{array}$ & $\begin{array}{l}\text { Inshore, sampled on } 1 \text { day } \\
\text { in Feb, Jul, Sep, Oct } 1993\end{array}$ & Stimson (1997) \\
\hline $\begin{array}{l}\text { Kaneohe Bay, } \\
\text { Hawaii }\end{array}$ & 0.62 & & 0.2 & $\begin{array}{l}\text { Reef flat, sampled every } \\
2 \text { to } 3 \text { d in A.pr to Jun } 1986\end{array}$ & Snidvongs \& Kinzie (1994) \\
\hline $\begin{array}{l}\text { Biscayne National } \\
\text { Park, Florida }\end{array}$ & $\begin{array}{c}0.58 \\
(0.52)\end{array}$ & & $\begin{array}{c}0.02 \\
(0.02)\end{array}$ & $\begin{array}{l}\text { Inshore, sampled high and low tide, } \\
\text { almost monthly Mar to Jul } 1990\end{array}$ & Szmant \& Forreste (1996) \\
\hline Key Largo, Florida & $\begin{array}{c}0.46 \\
(0.17)\end{array}$ & & $\begin{array}{c}0.01 \\
(0.20)\end{array}$ & $\begin{array}{l}\text { Inshore, sampled high and low tide, } \\
\text { almost monthly Mar to Jul } 1990\end{array}$ & Szmant \& Forrester (1996) \\
\hline Long Key, Florida & $\begin{array}{c}1.07 \\
10.56)\end{array}$ & & $\begin{array}{c}0.01 \\
(0.20)\end{array}$ & $\begin{array}{l}\text { Inshore, sampled high and low tide, } \\
\text { almost monthly Mar to Jul } 1990\end{array}$ & Szmant \& Forrester (1996) \\
\hline Barbados & $0.35-4.42$ & $0.03-0.73$ & $0.06-0.21$ & $\begin{array}{l}\text { Inshore, ranges of weekly samples in Mar } \\
\text { to Jul } 1990\end{array}$ & Tomascik \& Sander (1985) \\
\hline $\begin{array}{l}\text { Great Barrier Reef } \\
\text { (Cairns region) }\end{array}$ & $\begin{array}{c}0.06 \\
10.05)\end{array}$ & $\begin{array}{c}0.003 \\
(0.009)\end{array}$ & $\begin{array}{c}0.10 \\
(0.03)\end{array}$ & $\begin{array}{l}\text { Pristine reef areas, inshore-offshore sites, } \\
\text { May to Sep 1989-1991 }\end{array}$ & Furnas et al. (1995) \\
\hline $\begin{array}{l}\text { Great Barrier Reef } \\
\text { (Davies Reef) }\end{array}$ & $0.34-1.84^{\circ}$ & & $0.07-0.15$ & $\begin{array}{l}\text { Lagoon, range, sampled monthly from Jan } \\
\text { to Dec } 1990\end{array}$ & Ayukai (1993) \\
\hline $\begin{array}{l}\text { Tikehau Atoll, } \\
\text { French Polynesia }\end{array}$ & $\begin{array}{c}0.04 \\
(0.01)\end{array}$ & 0.02 & $\begin{array}{c}0.11 \\
(0.02)\end{array}$ & $\begin{array}{l}\text { Leeward reef, samples collected } \\
\text { every } 3 \text { h over } 24 \text { h on } 5 \text { d during Jan } 1991 \\
\text { to Mar } 1992\end{array}$ & Charpy et al. (1998) \\
\hline
\end{tabular}




\section{Photophysiological parameters in coral symbiotic algae}

Short-term data set (3 February to 23 March 1996) for Goniastrea aspera only

Algal cell density varied significantly (ANOVA: $p<$ $0.0001, \mathrm{n}=15$ ) between inclividual sampling dates (Fig. 4A) and showed a significant decrease over the $50 \mathrm{~d}$ period, reducing from a mean of 7.4 to $5.52 \times 10^{6}$ cells $\mathrm{cm}^{-2}$

\section{A}

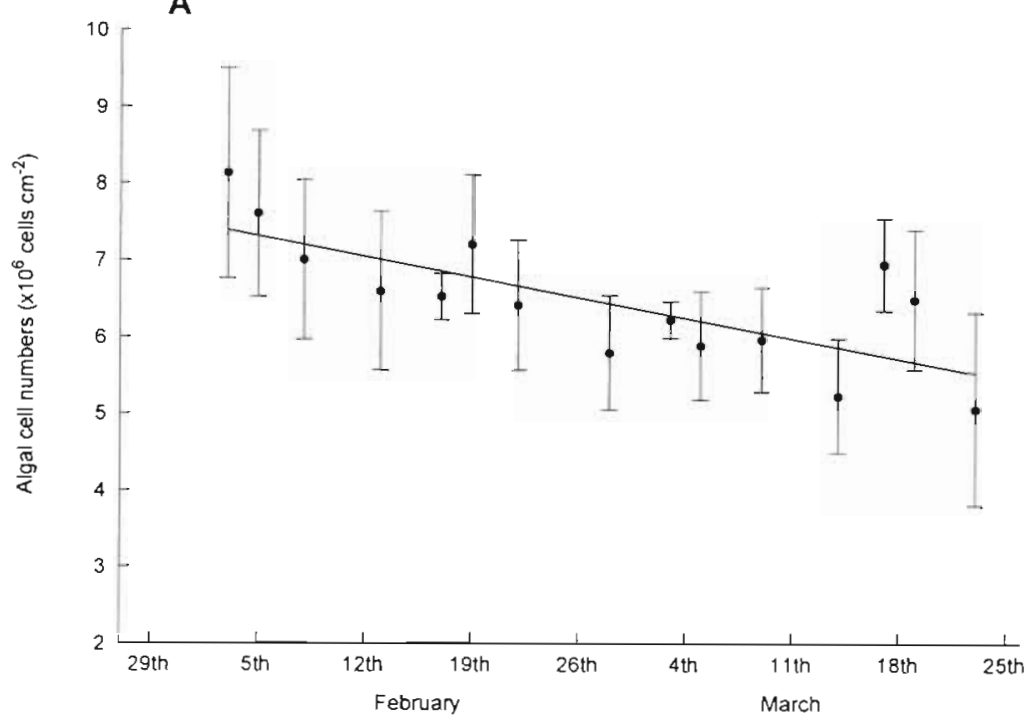

B

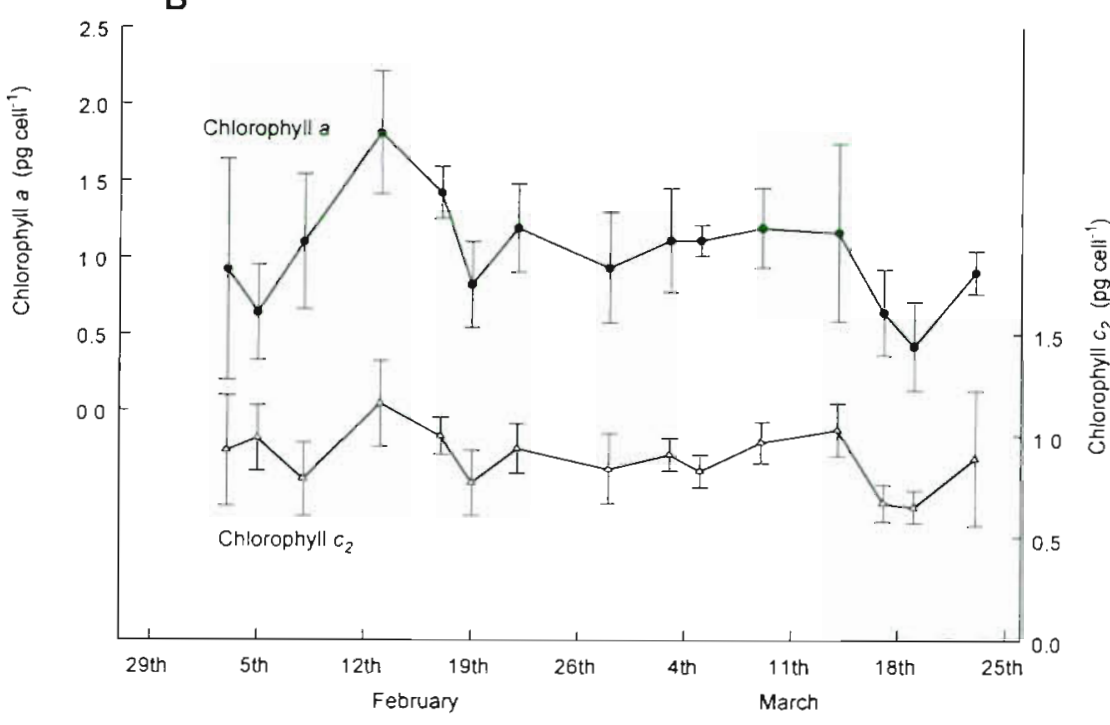

Fig. 4. (A) Algal cell density in Goniastrea aspera over the $50 \mathrm{~d}$ sampling period in 1996. The straight line is the best fit Jinear regression $(\mathrm{r}=-0.53, \mathrm{p}<0.0001$, $n=75$ ). (B) Algal cell concentration of chls $a$ and $c_{2}$. In both plots means $\pm 1 \mathrm{SD}$ are shown $(\mathrm{n}=5)$
The algal cell content of both chls a and $c_{2}$ also varied significantly (ANOVA: $p<0.0006, n=15$ ) between dates (Fig. 4B). In addition, the variations in the 2 pigments were positively correlated for each sample and at each date $(r=0.68, p<0.0001, n=75)$. Over the full sampling period, there was no trend in chl a content, but chl $c_{2}$ decreased ( $\left.\mathrm{p}=0.03, \mathrm{n}=75\right)$. This decrease in chl $c_{2}$ is, however, unlikely to be biologically important given the very low coefficient of determination $\left(\mathrm{r}^{2}=\right.$ 0.06 ) and large $95 \%$ confidence interval for the slope parameter $(-0.0003$ to -0.006$)$.

Both algal cell numbers and chlorophyll cell content were examined in the context of the SST and underwater PAR dose. Algal numbers were significantly correlated to the mean daily SST on the day of sampling $(r=-0.38$, $p=0.0007, \mathrm{n}=75$ ) and also to the PAR dose in the $24 \mathrm{~h}$ before sampling ( $\mathrm{r}=$ $-0.28, p=0.016, n=75$ ). Both chlorophyll pigments were similarly correlated to SST (chl $a: r=-0.33, p=0.004$; chl $c_{2}: r=-0.32, p=0.005 ; n=75$ ) but no direct relationship was found with the PAR dose.

\section{Long-term data set 1992 to 1996 for 4} species of reef flat corals

Temporal variability in algal densities and chlorophylls per cell was strongly correlated between 3 of the coral species, Coeloseris mayer, Porites lutea and Goniastrea retiformis (Figs, 5 to 7, Table 3 ). In the case of $G$. aspera, however, significant correlation was only found for algal density and algal chl $c_{2}$ with $G$. retiformis and $P$. lutea but not with $C$. mayeri. These differences in similarity may be associated with the relative positions of the species in the intertidal zone, $G$. aspera occupying the higher areas and C. mayeri the lowest.

\section{Algal density and changes in environmental factors}

Algal densities from all of the species were uniformly high throughout the time series (Fig. 5) compared to values commonly reported in the literature for other species of corals (Stim- 
son 1997). Densities ranged from 0.6 to $1.4 \times$ $10^{7}$ in Porites lutea, 0.4 to $1.8 \times 10^{7}$ in Goniastrea retiformis, and 0.8 to $2.6 \times 10^{7}$ in G. aspera and Coeloseris mayeri.

Variations in algal cell density revealed significant trends over time (ANOVA; KruskalWallis tests $p<0.0001$ ) with a common pattern in all 4 species. The general pattern in 1993, 1994 and 1995 is for the lowest algal density to occur towards the end of the dry season (March to May in 1993 and June in 1994) and for the highest algal density to be recorded at the end of the wet season/ beginning of the dry season (i.e. December 1993, November 1994). This conclusion was confirmed by statistical analysis of 3 of the 4 coral species (Coeloseris mayeri, Goniastrea retiformis, Porites lutea), with all showing significantly lower (SNK or Dunn's multiple comparison test $\mathrm{p}<0.01$ ) algal densities in March 1993 and May 1994, compared to November or December of the respective year. G. aspera showed a similar pattern to other corals in 1993, but in 1994 algal densities in March were not significantly different from those recorded in November. In 1995 algal densities recorded in May in C. mayeri and P. lutea were significantly lower (SNK or Dunn's multiple comparison test $p<0.01$ ) than those recorded in subsequent months of that year. For $G$. aspera and G. retiformis in 1995 algal densities were lowest (SNK or Dunn's multiple comparison test $p<0.05$ ) in May compared with June and July, respectively, with no significant differences apparent between May and November values in either coral species. In 1992 limited data from only 3 species of corals $(C$. mayeri, G. retiformis and $P$. lutea) suggested that algal densities did not conform to the patterns described above, with higher values ( $t$-tests in $P$. lutea and $G$. retiformis and ANOVA and SNK tests in $C$. mayeri $\mathrm{p}<0.008$ ) being recorded in March and July than in November.

Temporal variability in algal densities was also examined in the context of seasonal changes in both SST and daily mean PAR dose received by each coral species. For SST, the data set was compared with the corresponding monthly mean SST for the local sea area (MOHSST data), followed by the local thermistor data for successive periods of $30,14,7$, and $2 \mathrm{~d}$ immediately preceding the sampling date (mean SST in each case), and finally with the mean SST on the day of sampling. The bulk area SST showed the weakest relation-
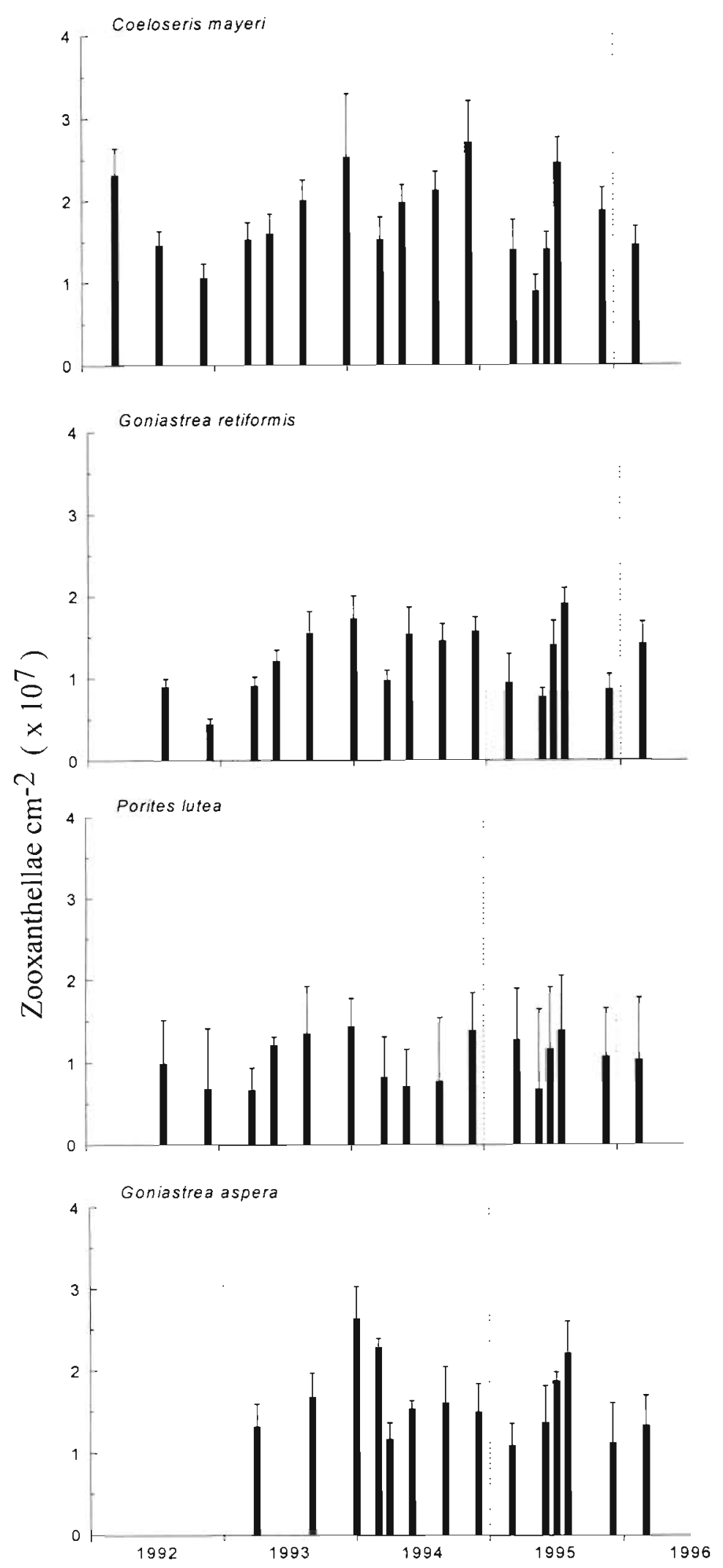

Fig. 5. Variation in symbiotic algae density for 4 coral species over a 4 yr monitoring period 1992 to 1996. Mean \pm 1 SD 

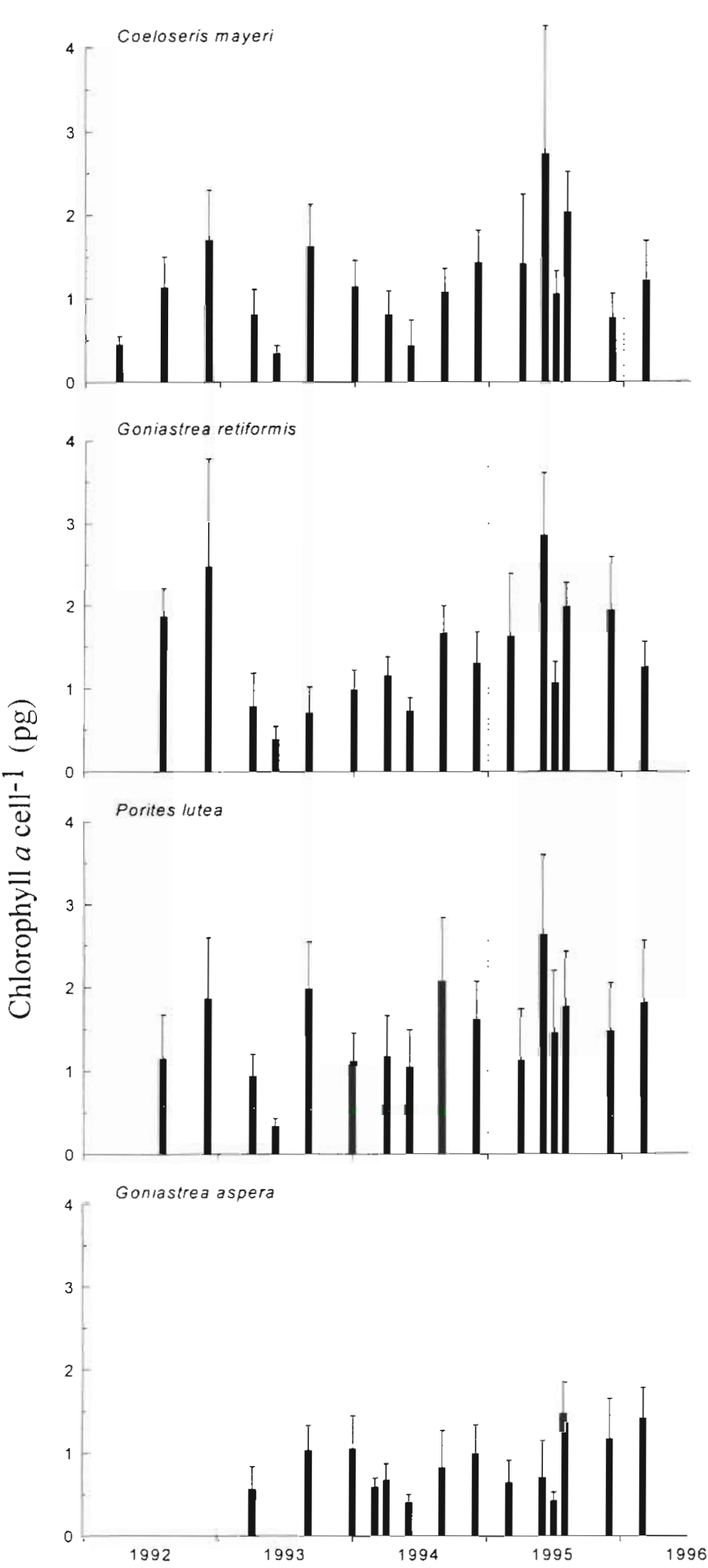

Fig. 6. Vanation in chl a concentration in algal cells of symbiotic algae for 4 coral species over a 4 yi monitoring period 1992 to1996. Mean $\pm 1 \mathrm{SD}$ ship (Table 4), with significant correlation for only 2 of the coral species. In contrast, the local temperature record demonstrated significant correlation for 3 of the 4 species at the monthly level, and in all other comparisons. Algal densities showed the greatest correlation with the mean SST in a short (2 d) time period just before sampling. The correlations were all negative, with algal densities reducing with increased SST. Furthermore, if the sampling dates of June and July 1995 are excluded from the analysis, on the basis that there is evidence of an overshoot in recovery of normal seasonal levels of algal numbers following a period of SST-induced bleaching in May 1995, then the SST correlation for the $2 \mathrm{~d}$ mean shows a dramatic increase in strength.

A similar analysis for algal densities against the PAR received by each species at their respective depth on the reef also gave rise to a significant relationship for all species except Porites Iutea. A succession of time intervals was chosen to examine the correlation coefficients for the mean daily PAR dose (mol $\mathrm{m}^{-2} \mathrm{~d}^{-1}$ ) preceding the sampling date. The daily PAR dose on the day of sampling consistently showed the greatest correlation (Table 5).

On the basis of the results obtained from the SST and PAR correlations, multiple regression models were fitted for the 3 species showing correlation with both SST and PAR, namely Coeloseris mayeri, Goniastrea retiformis, and $G$. aspera. The model terms which showed the best fit were in each case the mean SST and the PAR daily dose for the day of sampling. The coefficients of determination $\left(I^{2}\right)$ were $0.25,0.33$, and 0.44 for each species respectively $(\mathrm{p}<0.0001$ in all cases), and all the parameters for the terms were negative, indicating that in combination elevated SST and increased PAR dose were accompanied by a reduction in algal density,

\section{Algal chlorophylls}

Over the sampling period, mean algal chlorophyll a concentrations ranged between 0.33 and $2.85 \mathrm{pg} \mathrm{cell}^{-1}$ in Coeloseris mayeri, Goniastrea retiformis and Porites lutea, and 0.4 and $1.46 \mathrm{pg} \mathrm{cell}^{-1}$ in $G$. aspera, while chl $c_{2}$ ranged between 0.06 and $1.69 \mathrm{pg} \mathrm{cell}^{-1}$ in 
C. mayeri, G. retiformis and P. Lutea, and 0.25 and $0.89 \mathrm{pg} \mathrm{cell}^{-1}$ in $G$. aspera (Figs. 6 \& 7).

Temporal variation existed for both algal chlorophylls (ANOVA and Kruskal-Wallis $\mathrm{p}<$ $0.001)$ with significant differences $(p<0.05$ SNK or Dunn's multiple comparison test) between the lowest values of chl a recorded during a year (either in March or May) and higher values in the period August to December. This pattern was evident in Coeloseris mayeri for 1992, 1993 and 1994, in Goniastrea retiformis in 1993 and 1994, and in G. aspera in 1993 and 1994. In May 1995, when seawater temperatures were anomalously high, unusually high algal chl a values were recorded for C. mayeri, $G$. retiformis and P. lutea. Algal chl a concentrations were significantly higher in May than values in November in $C$. mayeri $(\mathrm{p}<0.001$ Dunn's multiple comparison test), than values in February and June in G. retiformis ( $p<0.0 .5$ Dunn's multiple comparison test), or than at any other time in the year for Porites lutea $(\mathrm{p}<$ 0.05 SNK).

A similar, but not identical, temporal pattern of variation was seen in algal chl $C_{2}$ concentrations with lower values recorded in May when compared to August in Coeloseris mayeri, Goniastrea retiformis and Pontes lutea in 1993 ( $p<0.05$ SNK and Dunn's multiple comparison test). In 1994 lower $c h l c_{2}$ values were noted in March/May compared with values in August in C. mayeri, G. retiformis, G. aspera and P. lutea $(p<0.01$ SNK and Dunn's multiple comparison test). In 1995 relatively high chl $c_{2}$ values were recorded in all corals in May, but only in the case of $C$. mayeri and $G$. aspera were these concentrations higher than values recorded later in the year in November.

There was no clear pattern in correlations between SST and algal chlorophylls for all species of corals. SST on the day of sampling showed a very weak positive correlation for both chls $a$ and $c_{2}$ in the case of Coeloseris mayeri (chl a: $\mathrm{r}=0.18, \mathrm{p}=0.04 ; \mathrm{chl} c_{2}: \mathrm{r}=0.24$, $\mathrm{p}=0.007 ; \mathrm{n}=125$ ) and a similarly weak positive correlation for chl a in Goniastrea retiformis ( $\mathrm{r}=0.23, \mathrm{p}=0.01, \mathrm{n}=119)$.

In contrast, PAR showed a general pattern of negative correlation with both chl $a$ and chl $c_{2}$, with the greatest correlation between the mean daily dose for the $5 \mathrm{~d}$ period immediately prior to sampling. In the case of $\mathrm{chl} a$, a significant relationship existed for 3 of the 4 species, and for chl $c_{2}$ for 2 species (Table 6 ).

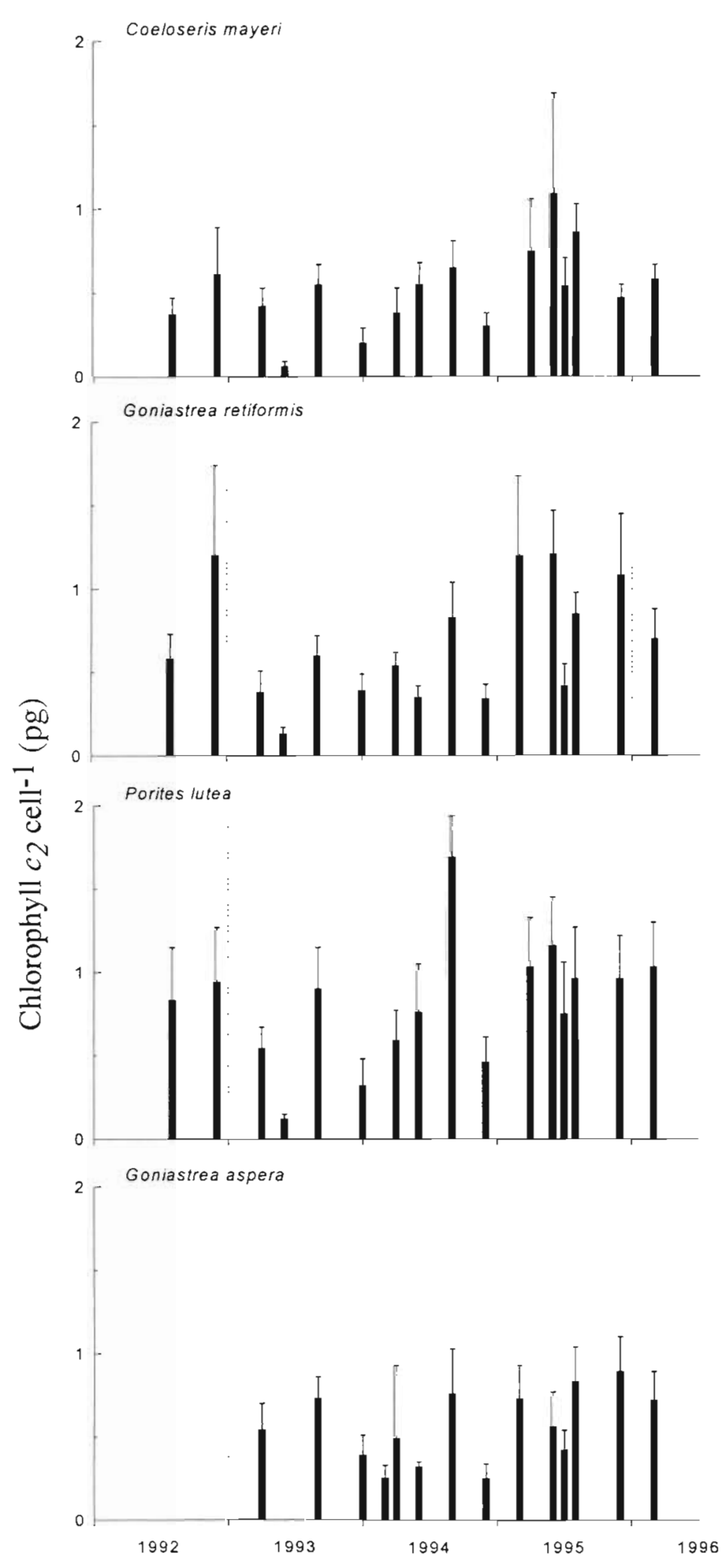

Fig. 7. Variation in chl $c_{2}$ concentration in algal cells of symbiotic algae for 4 coral species over a 4 yr monitoring period 1992 to 1996. Mean $\pm 1 \mathrm{SD}$ 
Algal volume

The cell volume of individual algae in Goniastrea retiformis was significantly larger (2-way ANOVA) in March 1994 (313 $\left.\mu^{3} \pm 10 \mathrm{SE}, \mathrm{n}=120\right)$ compared to December $1993\left(255 \mu \mathrm{m}^{3} \pm 13 \mathrm{SE}, \mathrm{n}=125\right)$, i.e. an increase of $23 \%$. Similar volume changes also appeared to be present in Porites lutea and Coeloseris mayeri (26 and $20 \%$ respectively) but the comparisons were accompanied by an interaction (within and between dates of sampling). There were no significant differences in algal cell volume for $G$. aspera sampled at different dates.

Table 3. Coeloseris mayeri, Goniastrea retiformis, Porites lutea and $G$. aspera. Correlation coefficients (and their significance values) between the 4 coral species for selected photophysiological parameters $(\cdots p<0.005 ; \cdots p<0.01 ; \cdot p<0.05$; ns $=$ not significant)

\begin{tabular}{|c|c|c|c|c|}
\hline Species & C. mayeri & G. retiformis & P. lutea & G. aspera \\
\hline \multicolumn{5}{|c|}{ Algal density $\mathrm{cm}^{-2}$} \\
\hline C. maуелі & - & $0,80 \cdots$ & $0.61 \cdots$ & ns \\
\hline G. retiformis & - & - & $0.68 \cdots$ & $0.78 \cdots$ \\
\hline P. lutea & - & - & - & $0.63^{\circ}$ \\
\hline G. aspera & - & - & - & - \\
\hline \multicolumn{5}{|l|}{ Chl a cell ${ }^{-1}$} \\
\hline C. Inaveri & - & $0.73 \cdots$ & $0.80^{\cdots}$ & ns \\
\hline G. retiformis & - & - & $0.70^{\cdots}$ & ns \\
\hline P. lutea & - & - & - & ns \\
\hline G. aspera & - & - & - & - \\
\hline \multicolumn{5}{|l|}{ Chl $c_{2}$ cell $^{-1}$} \\
\hline C. maveri & - & $0.74 \cdots$ & $0.75 \cdots$ & ns \\
\hline G. retiformis & - & - & $0.71 \cdots$ & $0.72 \cdots$ \\
\hline P. lutea & - & - & - & $0.65^{\circ}$ \\
\hline G. aspera & - & - & - & - \\
\hline
\end{tabular}

\section{DISCUSSION}

The published literature contains much evidence for the influences of irradiance, seawater temperatures, and nutrients upon photophysiological parameters in reef corals manipulated in controlled field and laboratory experiments. Stimson (1997) comprehensively reviewed this work and illustrated the often contradictory state of findings. In the case of a relationship between irradiance and algal density he concluded that there was no consistent pattern from a total of 11 experimental studies where irradiance was manipulated but that the majority of the work showed no changes in algal density with altered irradiance. He compared this to evidence from studies on colonies in their natural environment from different depths and different sun/shade conditions which reveal evidence of an inverse relationship between irradiance and algal density. The influence of seawater temperature on algal densities in reef anthozoans has previously been reported from laboratory manipulations where temperature elevations of 1 to $2^{\circ} \mathrm{C}$ above ambient elicit loss of algae (Hoegh-Guldberg \& Smith 1989, Glynn \& D'Croz 1990, Lesser et al. 1990, Sharp et al. 1997). In the field, however, evidence of sea temperature effects has been inferred from coral 'bleaching' events (Szmant \& Gassman 1990, Fitt et al. 1993, Jones 1997) but direct evidence is still lacking.

The present study has examined variations in SST, solar radiation and nutrients in the natural environment to aid our understanding of the potential effects of these physical influences on symbiotic algae in corals. To do so we have concentrated on measurements of algal cell density and chlorophyll pigments in

Table 4. Correlation statistics between sea-surface temperature (SST) and algal densities in the long-term data set from 1993 to 1996. MOHSST 6.1 is the bulk SST for the general area. Local thermistor data are from a thermistor $0.5 \mathrm{~m}$ below chart datum, $1 \mathrm{~km}$ from the study site. The last column is a $2 \mathrm{~d}$ mean excluding the months of June and July 1995

\begin{tabular}{|c|c|c|c|c|c|c|c|c|}
\hline \multirow{2}{*}{ Species } & \multirow{2}{*}{\multicolumn{2}{|c|}{$\begin{array}{l}\text { MOHSST } 6.1 \\
\text { monthly mean }\end{array}$}} & \multirow[b]{2}{*}{$30 \mathrm{~d}$} & \multirow[b]{2}{*}{$14 \mathrm{~d}$} & \multicolumn{2}{|c|}{ Local thermistor data } & \multirow[b]{2}{*}{ Sampling day } & \multirow[b]{2}{*}{$2 \mathrm{~d}$ mean } \\
\hline & & & & & $7 \mathrm{~d}$ & $2 d$ & & \\
\hline \multirow[t]{3}{*}{ Coeloseris mayeri } & r & -0.18 & -0.18 & -0.33 & -0.38 & -0.38 & -0.36 & -0.49 \\
\hline & p & 0.02 & 0.0067 & 0.0002 & $<0.0001$ & $<0.0001$ & $<0.0001$ & $<0.0001$ \\
\hline & $n$ & 135 & 125 & 125 & 125 & 125 & 125 & 110 \\
\hline \multirow[t]{3}{*}{ Goniastrea retiformis } & r & -0.089 & -0.19 & -0.21 & -0.28 & -0.31 & -0.30 & -0.51 \\
\hline & $\mathrm{p}$ & 0.318 & 0.04 & 0.02 & 0.002 & 0.0006 & 0.001 & $<0.0001$ \\
\hline & n & 129 & 119 & 119 & 119 & 119 & 119 & 104 \\
\hline \multirow[t]{3}{*}{ Porites lutea } & $\mathrm{r}$ & -0.26 & $-0,28$ & -0.23 & -0.24 & -0.24 & -0.22 & -0.35 \\
\hline & $\mathrm{p}$ & 0.002 & 0.0019 & 0.011 & 0.0076 & 0.0072 & 0.015 & 0.0002 \\
\hline & $\mathrm{n}$ & 135 & 125 & 125 & 125 & 125 & 125 & 110 \\
\hline \multirow[t]{3}{*}{ Goniastrea aspera } & r & 0.07 & -0.13 & -0.23 & -0.34 & -0.38 & -0.33 & -0.55 \\
\hline & $\mathrm{p}$ & 0.42 & 0.136 & 0.01 & 0.0001 & $<0.0001$ & 0.0002 & $<0.0001$ \\
\hline & $\mathrm{n}$ & 135 & 125 & 125 & 125 & 125 & 125 & 110 \\
\hline
\end{tabular}


Table 5. Correlation statistics for mean daily PAR dose and algal densities in the long-term data set 1993 to 1996

\begin{tabular}{|c|c|c|c|c|c|c|}
\hline \multirow{2}{*}{ Species } & \multicolumn{6}{|c|}{ Mean daily PAR dose $\left(\mathrm{mol} \mathrm{m}^{-2} \mathrm{~d}^{-1}\right)$} \\
\hline & & $30 \mathrm{~d}$ & $15 \mathrm{~d}$ & $5 d$ & $2 d$ & Sampling day \\
\hline \multirow{3}{*}{ Coeloseris mayeri } & r & -0.40 & -0.34 & -0.15 & -0.13 & -0.36 \\
\hline & $\mathrm{p}$ & $<0.0001$ & $<0.0001$ & 0.09 & 0.14 & $<0.0001$ \\
\hline & $\mathrm{n}$ & 135 & 135 & 135 & 135 & 135 \\
\hline \multirow[t]{3}{*}{ Goniastrea retiformis } & r & -0.51 & -0.45 & -0.25 & -0.33 & -0.50 \\
\hline & $\mathrm{p}$ & $<0.0001$ & $<0.0001$ & 0.0042 & 0.0002 & $<0.0001$ \\
\hline & $\mathrm{n}$ & 129 & 129 & 129 & 129 & 129 \\
\hline \multirow[t]{3}{*}{ Porites lutea } & $\mathrm{r}$ & -0.21 & -0.17 & +0.185 & +0.12 & -0.10 \\
\hline & $\mathrm{p}$ & 0.015 & 0.04 & 0.032 & 0.18 & 0.24 \\
\hline & $\mathrm{n}$ & 135 & 135 & 135 & 135 & 135 \\
\hline \multirow[t]{3}{*}{ Goniastrea aspera } & $r$ & -0.49 & -0.46 & -0.26 & -0.39 & -0.55 \\
\hline & $\mathrm{p}$ & $<0.0001$ & $<0.0001$ & 0.0026 & $<0.0001$ & $<0.0001$ \\
\hline & $\mathrm{n}$ & 135 & 135 & 135 & 135 & 135 \\
\hline
\end{tabular}

Table 6. Correlation statistics for chlorophyll pigments in algae and mean daily dose PAR $\left(\mathrm{mol} \mathrm{m}^{-2} \mathrm{~d}^{-1}\right)$ during $5 \mathrm{~d}$ prior to sampling

\begin{tabular}{|lcccccc|}
\hline Species & \multicolumn{4}{c}{ Chl a } & r & \multicolumn{2}{c|}{ Chl $c_{2}$} \\
& $\mathrm{r}$ & $\mathrm{p}$ & $\mathrm{n}$ & $\mathrm{r}$ & $\mathrm{n}$ \\
\hline Coeloseris mayeri & -0.29 & $<0.0001$ & 136 & -0.34 & $<0.0001$ & 135 \\
Goniastrea retiformis & -0.36 & $<0.0001$ & 129 & -0.16 & 0.08 & 129 \\
Ponites lutea & -0.46 & $<0.0001$ & 130 & -0.50 & $<0.0001$ & 131 \\
Goniastrea aspera & -0.12 & 0.92 & 134 & -0.01 & 0.91 & 134 \\
\hline
\end{tabular}

4 species of Indo-Pacific massive corals over a 4 yr time period, and also for 1 of the species over a short but intensively sampled $50 \mathrm{~d}$ period. Contemporaneously we have measured SST and solar radiation at the study site and combined these with information on nutrients to produce a high resolution physical data set.

Although our experimental location is a shallow water intertidal reef close to the equator $\left(7^{\circ} \mathrm{N}\right)$, the results are likely to be equally applicable to corals located in deeper water or at other latitudes. Indeed, at higher latitudes, 2 of the most important physical influences, namely SST and solar radiation, should normally be expected to have much greater seasonal variability, and therefore a correspondingly greater potential for influencing the photophysiology of the algae.

We have identified 2 key physical factors which appear to have a significant effect. These are the SST and solar radiation (PAR) received by the corals.

In the $50 \mathrm{~d}$ short-term study, we observed a significant steady decline in algal density and a parallel steady increase in SST over the duration of the period. At the same time there was no immediately apparent effect of PAR. More detailed investigation using correlation against the high resolution physical data sets demonstrated a significant correlation between SST and algal density and a weaker correlation for
PAR, both at a scale of $24 \mathrm{~h}$ prior to collection of the algae samples.

Analysis of the 4 yr sampling demonstrated convincingly that, for 3 of the 4 massive coral species, algal numbers varied in a like manner between sampling dates, and that, for all of the corals, algal densities declined to their minimum values at the end of the NE monsoon in the years 1993, 1994, and 1995, corresponding to the time of year when SST reaches its annual maximum. On closer examination there was clear evidence of a significant negative correlation between SST prior to the sampling dates and algal densities in all species. Taking the results from both studies together it thus seems undeniable that SST is a major factor directly influencing symbiotic algal density in these corals, and, furthermore, it would appear from the correlations observed that much of the effect is operating at a scale of days, rather than weeks

Our results for SST seem at first to be contradictory to work by Stimson (1997) and Fagoonee et al. (1999), neither of whom demonstrated any SST link. However, on closer inspection of those earlier studies, many confounding factors probably conspired to mask detection. Both studies used only a single species of branching coral (Pocillopora damicornis and Acropora formosa respectively) and sampled from the growing tips of these colonies, although Stimson (1997) attempted to 
minimise the variability associated with this sampling regime by avoiding the last 1 to $2 \mathrm{~cm}$ of the branch end. Stimson's correlations with SST were comparisons between the monthly mean SST over a number of years' pooled data and the mean of algal densities between different months in different years. It is therefore hardly surprising that he was unable to detect any relationship, given that our analysis showed that the correlation becomes weaker as the time scale is increased even to a monthly mean in the same year of sampling, let alone to a generalised annual pattern. Although Fagoonee et al. (1999) appear to have monitored temperature throughout their period of sampling, there is insufficient information on the nature of the data set acquired, or of the attempts at correlation. By inference, since their results for algal densities demonstrated considerable short-term variation, and from the remainder of their analysis, it would appear that they also had to compare pooled monthly temperature data from a number of years.

The correlation between algal cell density and PAR observed in our short-term study was also demonstrated in the long-term data. In both cases the strongest relationship existed at the time scale of PAR dose for the $24 \mathrm{~h}$ preceding the time of sampling. The lack of correlation for 1 of the species, Porites lutea, may in part be due to the morphology of this coral and the consequent limitations of our sampling methods. Unlike the other small massive species which we sampled, P. lutea typically occupies a position on the edge of intertidal pools, where its direction of growth is lateral. The resultant morphology makes it very difficult to sample cores where the orientation of the face of the core is in a horizontal plane. This means that the solar irradiance being received by the angled core surface will not match the downwelling PAR irradiance against which the correlation is made. Indeed for a difference of $30^{\circ}$ the error will be $14 \%$ (cosine law) without taking account of further errors due to the azimuth of the core surface and the variation in the above water and underwater light field at different times of year. Our results emphasise the vital need to consider the orientation of sampled coral surfaces and the measurement of the solar flux from which any comparisons are drawn.

Comparing our results to those of Fagoonee et al. (1999) and Stimson (1997), it is unlikely that the former would have detected any PAR effect from data obtained from the Mauritius Meteorological Office at the scale of monthly means and for differently oriented branches sampled from the coral. Stimson (1997) reports a correlation between the monthly mean irradiance (and ultraviolet radiation [UVR]) and algal density but none of his samples were taken in the $16 \mathrm{mo}$ period when irradiance was recorded or the 28 mo period when UVR records were collected. Furthermore, his correlation coefficients were for mean values of algal densities rather than the full variation in individual samples, and he does not report the corresponding probabilities for each coefficient. In such circumstances care needs to be taken in inferring biologically meaningful correlations, since the effect of using means will always be to overestimate the correlation coefficient. Our own results consistently show that the greatest correlation of PAR with algal cell density is at the scale of the day of sampling. Similarly, our earlier observations on solar bleaching in Goniastrea aspera also demonstrate that dramatic reductions in algal densities occur within a very short time scale (24 h) of exposure to high solar radiation (Brown et al. 1994). Given this scenario it is likely that Stimson (1997) was detecting a connectivity, whereby irradiance (and UVR) was correlated to time of year, and algal density was also correlated with the same time of year, giving rise to an 'apparent' direct correlation between the two. This is particularly likely given the short time scale of his solar radiation measurements and the lack of any contemporaneity in the data sets.

Our multiple regression analyses of SST and PAR demonstrate their combined role on the algal density in 3 of the species in the long-term sampling study, such that the model explained between 25 and $44 \%$ of the reductions in density for increases in SST and PAR. It is likely that in both cases PAR and SST are interacting to reduce algal numbers through photosynthetic damage, as described by Warner et al. (1996), Brown (1997b), and Iglesias-Prieto (1997).

For the algal chlorophyll concentrations, while the short-term study showed no clear picture, the longerterm data collected over the period 1992 to 1994 showed an annual pattern of reduced algal chlorophylls at the end of the dry season and increased algal chlorophylls at the end of the wet monsoon. Significant correlations between algal chlorophylls and the actual PAR received by the corals over the preceding $5 \mathrm{~d}$ suggest a pattern of acclimatisation to ambient irradiance levels. Our results are, therefore, a confirmation of the depth and sun/shade interactions which other workers have previously observed (reviewed by Falkowski et al. 1990). Similarly, in a recent study of the effect of seasonality on chlorophyll content of symbiotic algae extracted from the jellyfish Cassiopea xamachana, algal chlorophylls were also highest when irradiance levels were lowest (Verde \& McCloskey 1998).

The role of nutrients in influencing algal densities and algal chlorophylls in the present study is less clear. The concentration of dissolved nutrients, although high all year round (Table 2) as a result of drainage from extensive mangroves to the north, and oceanic upwelling offshore (Janekarn \& Hylleberg 1989), is 
extremely variable and shows no overall marked seasonal pattern. Inshore waters at the site have a high particulate load which frequently reaches 20 to $40 \mathrm{mg}$ $\mathrm{l}^{-1}$ (Scoffin et al. 1992, Panutrakul 1996). Particulates are derived from fine terrigeneous sediments which are composed of clay minerals. It is likely that these particulates, coated with bacteria and micro-algae, present added potential nutrients to particulate feeding corals in the region (Mills \& Sebens 1997, Anthony 1999). From the fore-going it would seem likely that nutrients are rarely limited in this turbid inshore environment.

The unusually high algal densities observed in all coral species analysed at Phuket may be the result of living in waters with high nutrient levels. Massive corals from inshore turbid waters in Singapore (Goh unpubl.) and Java (Suharsono \& Soekarno 1983) show similar high algal densities. However, the algae in the sampled corals were also markedly smaller (Brown et al. 1995 and this study) than those recorded in the majority of Caribbean corals (Wilkerson et al. 1988), and in corals investigated on the Great Barrier Reef (Hoegh-Guldberg \& Smith 1989, Jones \& Yellowlees 1997). Such high densities of relatively small algae may be due to the rapid growth of both algae and host tissues (Wilkerson et al. 1988, Jones \& Yellowlees 1997), particularly during the wet season, when environmental factors are more favourable than the dry season. Alternatively, size may be determined by genetic composition; the only alga thus far characterised from corals at this site being a relatively novel 'type e' from Goniastrea aspera (Goodson unpubl.).

Both algal cell volume and coral tissue depth appear, from the limited data sets available, to vary between seasons, with significantly larger algae (between 20 and $26 \%$ volume increase) at the end of the dry season (when algal densities are low) than at the end of the wet season (when algal densities are high). Tissue depth in Goniastrea aspera is almost 2-fold greater at the end of the wet season than during the dry season (Brown unpubl.) while similar results may be inferred for Porites lutea from the markedly different skeletal extension rates noted between the 2 seasons (Barnes \& Lough 1992, Scoffin et al. 1992). If space availability and algal size are critical factors in the regulation of algal densities, as argued by Jones \& Yellowlees (1997), then the increased algal numbers noted at the end of the wet season may well be explained by rapid growth of both host and algal cells. Such effects could be promoted by relaxation of stressful environmental influences, such as seawater-temperature/irradiance interactions, that prevail during the dry season earlier in the year.
During April and May 1995, when seawater temperatures were anomalously high (Fig. 3A) and extensive bleaching was noted (Brown et al. 1996), algal densities in pale pigmented corals were low, but for most species no lower than those recorded in March to May of previous years. Our results indicate that even in a 'normal' year algal densities are reduced by as much as $53 \%$ below their seasonal maximum, compared to reductions of about $86 \%$ which were observed in white colonies during the 1995 bleaching (Table 7).

Interestingly, in May 1995 algal chl a levels were generally very high (and variable) in pale pigmented corals whereas 1 mo later chl a levels were significantly reduced. Elevated chl a levels in bleached corals have been previously reported by Hoegh-Guldberg \& Smith (1989), Szmant \& Gassman (1990), Fitt et al. (1993), Le Tissier \& Brown (1996), and Jones (1997). Explanations of such observations have included: (1) a response of remnant algae to increased nutrient availability through decreased competition from other algae (Fitt et al. 1993, Jones 1997), or (2) the greater loss of apical algae, leaving dark-adapted algae with high chlorophyll concentrations in the strongly retracted tissues below (Brown et al. 1995, Le Tissier \& Brown 1996). In May 1995, although SST was high, PAR levels had already fallen and were at the normal wet monsoon low for up to $2 \mathrm{wk}$ prior to sampling. Increased algal chlorophylls may therefore be a result of photacclimatisation to reduced irradiance as well as the explanations given above.

This study has highlighted the importance of seasonal environmental influences on fundamental photophysiological parameters in corals. The effect of seasonality is likely to be even more pronounced in higher latitude locations like Hawaii (Stimson 1997), Mauritius (Fagoonee et al. 1999) and the Bahamas (Fitt et al. in press). The seasonal changes in algal density reported in these studies and our own observations strongly suggest that there is a natural annual pattern of changes in the status of the algal/coral symbiosis; the alterations which result being directly influenced by changing solar radiation and seawater temperature. Not only do these studies put the widely reported

Table 7. Algal density and chlorophyll per algal cell for bleached coral colonies in June 1995 ( $n=5$ in each case). Mean valuns \pm 1 SD nd: not detectable

\begin{tabular}{|c|c|c|c|}
\hline Species & $\begin{array}{l}\text { Algal density } \\
\left(\times 10^{7} \mathrm{~cm}^{-2}\right)\end{array}$ & $\begin{array}{l}\text { Chl a/alga } \\
\left.(\mathrm{pg} \mathrm{cell-1})^{-1}\right)\end{array}$ & $\begin{array}{l}\text { Chl } c_{2} \text { /alga } \\
\left(\mathrm{pg} \mathrm{cell}{ }^{-1}\right)\end{array}$ \\
\hline Coeloseris mayeri & $0.054(0.04)$ & $1.52(1.26)$ & $1.88(1.82)$ \\
\hline Porites lutea & $0.190(0.09)$ & $1.24(0.90)$ & $0.29(0.20)$ \\
\hline Goniastrea retiformis & $0.026(0.014)$ & nd & $0.98(0.45)$ \\
\hline Goniastrea aspera & $0.109(0.11)$ & $1.00(0.09)$ & $0.17(0.15)$ \\
\hline
\end{tabular}


'bleaching' phenomenon in perspective, but they also serve to heighten the potential for important changes in physiological performance of corals at different times of the year

Acknowledgements. We are grateful for financial support from a number of organisations during the course of this study: the United Kingdom Department for International Development, the Natural Environment Research Council, and the Royal Society. We are particularly indebted to Vudhichai Janekarn and Somkiat Khokiattiwong for generous providing access to nutrient data, and to the Director of the Phuket Marine Biological Center, Mr Prawin Limpsaichol.

\section{LITERATURE CITED}

Adey WH (1998) Coral reefs: algal structured and mediated ecosystems in shallow turbulent, alkaline waters. J Phycol 34:393-406

Anthony KRN (1999) Coral suspension feeding on fine particulate matter. J Exp Mar Biol Ecol 232:85-106

Ayukai $T$ (1993) Temporal variability of the nutrient environment on Davies Reef in the central Great Barrier Reef, Australia. Pac Sci 47:171-179

Barnes DJ, Lough JM (1992) Systematic variations in the depth of skeleton occupied by coral tissue in massive colonies of Porites from the Great Barrier Reef. J Exp Mar Biol Ecol 159:113-128

Brown BE (1997a) Adaptations of reef corals to physical environmental stress. Adv Mar Biol 31:221-299

Brown BE (1997b) Coral bleaching: causes and consequences. Coral Reefs 16(Suppl):S129-S138

Brown BE, Le Tissier MDA, Howard LS, Charuchinda M, Jackson JA (1986) Asynchronous deposition of dense skeletal bands in Porites lutea. Mar Biol 93:83-89

Brown BE, Dunne RP, Scoffin TP, Le Tissier MDA (1994) Solar damage in intertidal corals. Mar Ecol Prog Ser 105: $219-230$

Brown BE, Le Tissier MDA, Bythell JC (1995) Mechanisms of bleaching deduced from histological studies of reef corals sampled during a natural bleaching event. Mar Biol 122: 655-663

Brown BE, Dunne RP, Chansang $H$ (1996) Coral bleaching relative to elevated seawater temperature in the Andaman Sea (Indian Ocean) over the last 50 years. Coral Reefs 15: $151-152$

Buddemeier RW, Kinzie RA (1976) Coral growth. Oceanogr Mar Biol Annu Rev 14:183-225

Chambers DP, Tapley BD, Stewart RH (1999) Anomalous warming in the Indian Ocean coincident with El Niño. J Geophys Res 104:3035-3047

Charpy L, Charpy-Roubaud C, Buat P (1998) Excess primary production, calcification and nutrient fluxes of a patch reef (Tikehau atoll, French Polynesia). Mar Ecol Prog Ser 173: $139-147$

Chornesky EA, Peters EC (1987) Sexual reproduction and colony growth in the scleractinian coral Porites astreoides. Biol Bull 172:161-177

Done T (1992) Constancy and change in some Great Barrier Reef coral communities: 1980-1990. Am Zool 32:655-662

Dunne RP (1994) Environmental data handbook for Phuket Marine Biological Centre, Thailand. Overseas Development Administration, London

Fagoonee I, Wilson HB, Hassell MP, Turner JR (1999) The dynamics of zooxanthellae populations: a long-term study in the field. Science 283:843-845

Falkowski PG, Jokiel PL, Kinzie RA (1990) Irradiance and corals. In: Dubinsky Z (ed) Ecosystems of the world: coral reefs, Vol 25. Elsevier Science Publishing Company, New York, p 89-107

Fitt WK, Spero HJ, Halas J, White MW, Porter JW (1993) Recovery of the coral Montastrea annularis in the Florida Keys after the 1987 Caribbean 'bleaching event'. Coral Reefs 12:57-64

Fitt WK, McFarland F, Warner ME, Chilcoat G (in press) Seasonal patterns of tissue biomass and densities of symbiotic dinoflagellates in reef corals, and relation to corals bleaching. Limnol Oceanogr

Furnas MJ, Mitchell AW. Skuza M (1995) Nitrogen and phosphorus budgets for the central Great Barrier Reef. Great Barrier Reef Marine Park Authority, Townsville

Glynn PW, D'Croz L (1990) Experimental evidence for high temperature stress as the cause of El Niño-coincident coral mortality. Coral Reefs 8:181-192

Green CF, Deuchar CN (1985) On improved tube solarimeter construction. J Exp Bot 36:690-693

Gregg WW, Carder KL (1990) A simple spectral solar irradıance model for cloudless maritime atmospheres. Limnol Oceanogr 35:1657-1675

Harrison PL, Wallace CC (1990) Reproduction, dispersal and recruitment of scleractinian corals. In: Dubinsky $Z$ (ed) Ecosystems of the world: coral reefs, Vol 25. Elsevier Science Publishing Company, New York, p 133-207

Hoegh-Guldberg O, Smith GJ (1989) The effect of sudden changes in temperature, light and salinity on the population density and export of zooxanthellae from the reef corals Stylophora pistillata Esper and Seriatopora hystrix Dana. J Exp Mar Biol Ecol 129:279-304

Iglesias-Prieto R (1997) Temperature-dependent inactivation of photosystem II in symbiotic dinoflagellates. Proc 8 th Int Coral Reef Symp 2:1313-1318

Janekarn V. Hylleberg J (1989) Coastal and offshore primary production along the west coast of Thailand (Andaman Sea) with notes on physical-chemical variables. Phuket Mar Biol Cent Res Bull 51:1-20

Jeffrey SW, Haxo FT (1968) Photosynthetic pigments of symbiotic dinoflagellates (zooxanthellael from corals and clams. Biol Bull 135:149-165

Jeffrey SW, Humphrey GP (1975) New spectrophotometric equations for determining chlorophylls $a, b$, and $c 1$ and $c 2$ in higher plants, algae and natural phytoplankton. Biochem Physiol Pflanz 167:191-194

Jokiel PL, Coles SL (1974) Effects of heated effluent on hermatypic corals at Kahe Point, Oahu. Pac Sci 28:1-18

Jones RJ (1997) Changes in zooxanthellar densities and chlorophyll concentrations in corals during and after a bleaching event. Mar Ecol Prog Ser 158:51-59

Jones RJ, Yellowlees D (1997) Regulation and control of intracellular algae (= zooxanthellae) in hard corals. Phil Trans $R$ Soc Lond B Biol Sci 352:457-468

Lesser MP, Stochaj WR, Tapley DW, Shick JM (1990) Bleaching in coral reef anthozoans: effects of irradiance, ultraviolet radiation, and temperature on the activities of protective enzymes against active oxygen. Coral Reefs 8:225-232

Le Tissier MDA, Brown BE (1996) Dynamics of solar bleaching in the intertidal reef coral Goniastrea aspera at Ko Phuket, Thailand. Mar Ecol Prog Ser 136:235-244

Mills MM, Sebens KP (1997) Particle ingestion efficiency of the coral Siderastrea siderea and Agaricia agaricites: effects of flow speed and sediment loads. Proc 8th Int Coral Reef Symp 2:1059-1064 
Newell ND (1971) An outline history of tropical organic reefs. Am Mus Novit 2465:1-37

Panutrakul S (1996) Water quality in Phuket Bay. Phuket Mar Biol Cent Res Bull 61:67-81

Parker DE, Folland CK, Jackson M (1995) Marine surface temperature: observed variations and data requirements. Clim Change 31:559-600

Rinkevich B (1989) The contribution of photosynthetic products to coral reproduction. Mar Biol 101:259-264

Rinkevich B, Loya Y (1987) Variability in the pattern of sexual reproduction of the coral Stylophora pistillata at Eilat, Red Sea: a long-term study. Biol Bull 173:335-344

Scoffin TP, Tudhope AW, Brown BE, Chansang H, Cheeney RF (1992) Patterns and possible environmental controls of skeletogenesis of Porites lutea, South Thailand. Coral Reefs 11:1-11

Sharp VA, Brown BE, Miller D (1997) Heat shock protein (hsp 70 ) expression in the tropical reef coral Goniopora djiboutiensis. J Therm Biol 22:11-19

Snidvongs A, Kinzie RA III (1994) Effects of nitrogen and phosphorus enrichment on in vivo symbiotic zooxanthellae of Pocillopora damicornis. Mar Biol 118:705-711

Stimson $J(1997)$ The annual cycle of density of zooxanthellae in the tissues of field and laboratory-held Pocillopora damicornis. J Exp Mar Biol Ecol 214:35-48

Stoddart JA, Black R (1985) Cycles of gametogenesis and planulation in the coral Pocillopora damicornis. Mar Ecol Prog Ser 23:153-164

Strickland JDH, Parsons TR (1968) A practical handbook of seawater analysis. Bull Fish Res Board Can 167

Suharsono, Soekarno (1983) Kandungan zooxanthella pada karang batu di terumbu karang Pulau Pari. Oseanol Indones 16:1-7

Szeicz G, Monteith JL, Dos Santos JMI (1964) Tube solarimeter

Editorial responsibility: Otto Kinne (Editor),

Oldendorf/Luhe, Germany to measure radiation among plants. J Appl Ecol 1:169-174 Szmant AM, Forrester A (1996) Water column and sediment nitrogen and phosphorus distribution patterns in the Florida Keys, USA. Coral Reefs 15:21-41

Szmant AM, Gassman NJ (1990) The effects of prolonged 'bleaching' on the tissue biomass and reproduction of the reef coral Montastrea annularis. Coral Reefs $8: 217-224$

Tomascik T, Sander F (1985) Effects of eutrophication on reefbuilding corals: 1 Growth rate of the reef-building coral Montastrea annularis. Mar Biol 87:143-156

Van Veghel MLJ, Bak RPM (1994) Reproductive characteristics of the polymorphic Caribbean reef building coral Montastrea annularis 3. Reproduction in damaged and regenerating colonies. Mar Ecol Prog Ser 109:229-233

Verde EA, McCloskey LR (1998) Production, respiration, and photophysiology of the mangrove jellyfish Cassiopea xamachana symbiotic with zooxanthellae: effect of jellyfish size and season. Mar Ecol Prog Ser 168:147-162

Veron JEN (1995) Corals in space and time: the biogeography and evolution of the scleractinia. Cornell University Press, Ithaca

Wallace CC (1985) Seasonal peaks and annual fluctuations in recruitment of juvenile scleractinian corals. Mar Ecol Prog Ser 21:289-298

Warner ME, Fitt WK, Schmidt GW (1996) The effects of elevated temperature on the photosynthetic efficiency of zooxanthellae in hospite from four different species of reef coral: a novel approach. Plant Cell Environ 19:291-299

Wilkerson FP, Kobayashi D, Muscatine L (1988) Mitotic index and size of symbiotic algae in Caribbean reef corals. Coral Reefs 7:29-36

Woodley JD (1992) The incidence of hurricanes on the north coast of Jamaica since 1870 - are the classic reef descriptions atypical. Hydrobiologia 247:133-138

Submitted: May 3, 1999; Accepted: August 9, 1999

Proots received from author(s): December 21, 1999 